\title{
Adaptive Responses of Paspalum oteroi Native Grass to Fertilization and Shading
}

\author{
Alex Coene Fleitas (Corresponding author) \\ State University of Mato Grosso do Sul - University Unit of Aquidauana \\ Rodovia Graziela Maciel Barroso, Km 12 Zona Rural, Aquidauana, Mato Grosso do Sul, \\ Brazil. E-mail: alex.c.fleitas@gmail.com \\ Luísa Melville Paiva \\ State University of Mato Grosso do Sul - University Unit of Aquidauana \\ Rodovia Graziela Maciel Barroso, Km 12 Zona Rural, Aquidauana, Mato Grosso do Sul, \\ Brazil. E-mail: lumelville@gmail.com
}

Sandra Aparecida Santos

Embrapa Pantanal - CPAP, St. 21 de September, Nossa Senhora de Fátima,

Corumbá, Mato Grosso do Sul, Brazil. E-mail: sandra.santos@embrapa.br

Henrique Jorge Fernandes

State University of Mato Grosso do Sul - University Unit of Aquidauana

Rodovia Graziela Maciel Barroso, Km 12 Zona Rural, Aquidauana, Mato Grosso do Sul, Brazil. E-mail: henrique.uems@hotmail.com

Redney Gomes Brevilieri

State University of Mato Grosso do Sul - University Unit of Aquidauana

Rodovia Graziela Maciel Barroso, Km 12 Zona Rural, Aquidauana, Mato Grosso do Sul,

Brazil. E-mail: redney_rgb@hotmail.com 
Patricia Gomes dos Santos

State University of Mato Grosso do Sul - University Unit of Aquidauana

Rodovia Graziela Maciel Barroso, Km 12 Zona Rural, Aquidauana, Mato Grosso do Sul,

Brazil. E-mail: psg_patricia.gomes@hotmail.com

Received: May 13, 2020 Accepted: June 16, $2020 \quad$ Published: June 22, 2020

doi:10.5296/jas.v8i3.17227

URL: https://doi.org/10.5296/jas.v8i3.17227

\begin{abstract}
The aim of this study was to evaluate the Paspalum oteroi native grass and its adaptive responses to shading and foliar fertilization in two pasture systems in the Cerrado-Pantanal transition region. A completely randomized block design with factorial arrangement was adopted to this study: three types of fertilizers [no fertilization - control (C); Foliar fertilizer for pasture (FF) and Soil fertilizer + Foliar fertilizer (SF)] x two pasture systems (WS - with shading, wooded $P$. oteroi pasture; NS - no shading, exclusive $P$. oteroi pasture) with four repetitions. $P$. oteroi seedlings were transplanted in November 2015. Data collection was from May 2016 to September 2016, during dry season. There were differences $(p<0.05)$ in the sward height variables $(\mathrm{H})$, dry matter (DM), crude protein $(\mathrm{CP})$ content, dry matter production (DMP) and shoot: root ratio (S:R). In the WS system increased of $8,61 \%$ of the CP content and fertilizer SF increased of $8.81 \%$ of the CP content. However, in the WS system was observed reduced DM, DMP and S:R and in the FF and SF fertilizers increased leaf area index (LAI), in the latter months of the application. Probably, P. oteroi grass developed adaptation strategies to deal with the environmental conditions to which it was submitted during this study, such as variations in its morphophysiological traits: low shoot / root ratio, height, chemical composition, leaf area index e light interception. In conclusion, $P$. oteroi showed adaptation to wooded pasture systems, during dry period, however, the use of fertilization depends on economic viability studies.
\end{abstract}

Keywords: leaf area index, light interception, native forage resource, silvopastoral systems, chemical composition

\title{
1. Introduction
}

In general, water shortage, and light and soil nutrient availability are considered resources that limit plant growth in grasslands (Craine e Dybzinski, 2013; Siebenkäs et al., 2015), affecting pasture productivity and nutrient supplies for the animals. On the other hand, integrated crop-livestock systems, such as the silvopastoral system, have been used to optimize the sustainability of pastures through the production of wood-based and forage. In addition to this, the silvopastoral system can result in accumulated soil $\mathrm{C}$ and reduced emissions of greenhouse gases, increasing economic and environmental outcome (Balbino et 
al., 2012; Salton et al., 2014).

Integrated systems must be designed differently among the Brazil regions according to specific characteristics (Salton et al., 2014). Savannas cover very extensive areas of Central Brazil including Pantanal, highlighting the importance of the Cerrado-Pantanal interface. One of the most frequent demands of the savanna region has been shade tolerant grasses aiming at pasture-forest production systems, however, these forages are limited (Euclides et al., 2010). Thus, studies with different forages are fundamental to evaluate tolerance and development under conditions of restricted luminosity (Carvalho et al., 2002).

In Brazil, only a few genera and species of forages are being studied focusing mainly on exotic species (Euclides et al., 2010). Thus, the research for native forage has a great relevance for the region and the country. In Pantanal, several grasses with potential for management and cultivation have been identified, but studies involving characterization and responses to different environmental conditions are yet to be done (Santos et al., 2011). Physiological and morphological plasticity may have a different role in plant adaptation so that it can deal with the environmental factor variability (Gratani, 2014).

Another limiting factor in the savanna region refers to soil fertility which is considered to have low and intermediate fertility, which may adversely affect the pastures establishment (Euclides et al., 2010). Besides the fact that the interaction of light and soil fertility on forage trait expressions have been poorly studied (Siebenkäs et al., 2015).

The aim of this study was to evaluate the Paspalum oteroi native grass and its adaptive responses to shading and foliar fertilization in two pasture systems in the Cerrado-Pantanal transition region.

\section{Method}

This work was carried out in a transition region from Cerrado-Pantanal, Aquidauana, Mato Grosso do Sul, Brazil. The experimental area belongs to State University of Mato Grosso do

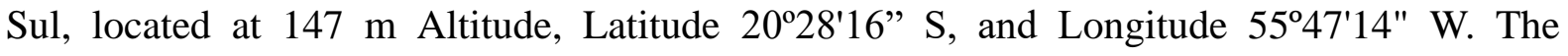
experiment was carried out from November 2015 (planting) to September 2016. The climate is AW (humid tropical), according to the climatic classification of Köppen. The climatic conditions during the study period are showed in the Figure 1. 


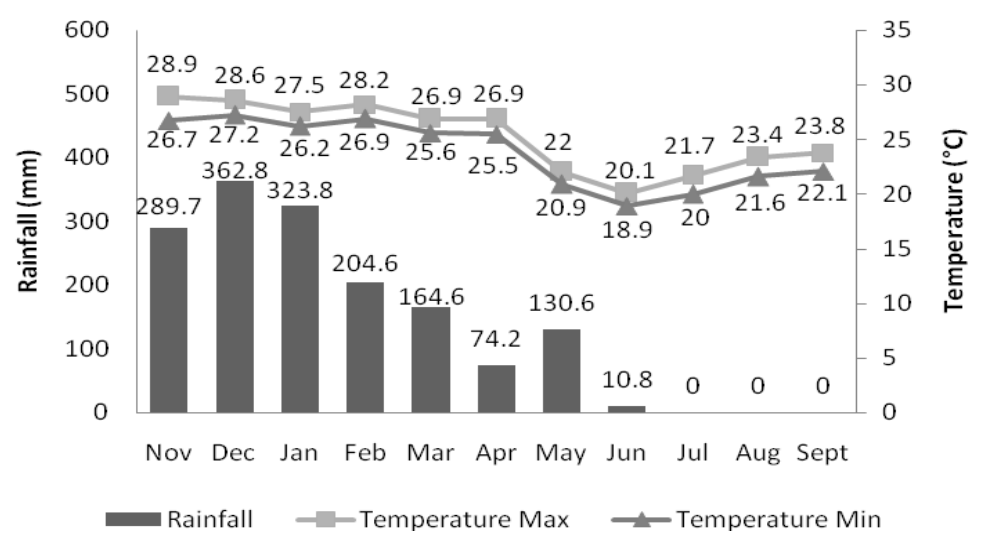

Figure 1. Accumulated rainfall, and minimum and maximum temperatures from November 2015 to September 2016, according to the National Meteorological Institute of the Municipality of Aquidauana - MS (Inmet, 2016)

Seedlings of the Paspalum oteroi native grass growing in their natural environment, in the region recognized as Nhecolandia's Pantanal (at Latitude $18^{\circ} 59^{\prime} \mathrm{S}$ and Longitude $56^{\circ} 39^{\prime} \mathrm{W}$ ). These seedlings were collected, stored in wet newspaper, and finally transported to the experimental area, transplanted, and cultivated. Plant density was 10 plants $\mathrm{m}^{-1}$, with $10 \mathrm{~cm}$ spacing between plants.

This study was conducted adopting a completely randomized block design (CRBD) with factorial arrangement $3 \times 2$ : three types of fertilizers [No fertilization - control (C); Foliar fertilizer for pasture (FF) and Soil fertilizer + Foliar fertilizer (SF)] x two pasture systems (WS - with shading, wooded $P$. oteroi pasture; NS - no shading, exclusive $P$. oteroi pasture) with four repetitions each one. The experimental area had two hectares with one hectare for each pasture system. The shading of the first treatment was provided by trees of Terminalia spp, and Paspalum oteroi was cultivated between them. The area of the NS treatment had only Paspalum oteroi cultivated (with no natural or artificial shadow).

An inventory of all trees dispersed in WS system was conducted to characterize and describe richness, sociability, composition, and cover type characterization. In that area, just the Terminalia spp was identified, in an isolated grouping, totalling 19 trees distributed randomly among the plots. To characterize the treetop type and shadow projected by Terminalia spp, it was used the methodology cited by Da Silva et al. (2006). Terminalia spp. has inverted conic treetop and its shadows projections calculated for this type of cup. Average shade of the trees was $58.2 \mathrm{~m}^{2}$, and the total area of shade was $1,105 \mathrm{~m}^{2}$.

Random soil samples were taken at $0-20 \mathrm{~cm}$ depth at the beginning of the experiment for chemical analysis. The samples were air-dried, processed, and sent to the chemical analysis laboratory. Based on the results (Table 1) it was not necessary to correct the $\mathrm{pH}$ and fertilize soil with potassium or other fertilizers than phosphorus. 
Table 1. Results of soil sample's chemical analysis, and relationships between these chemical components, in two systems of pastures (with shading - WS; and without shading - NS)

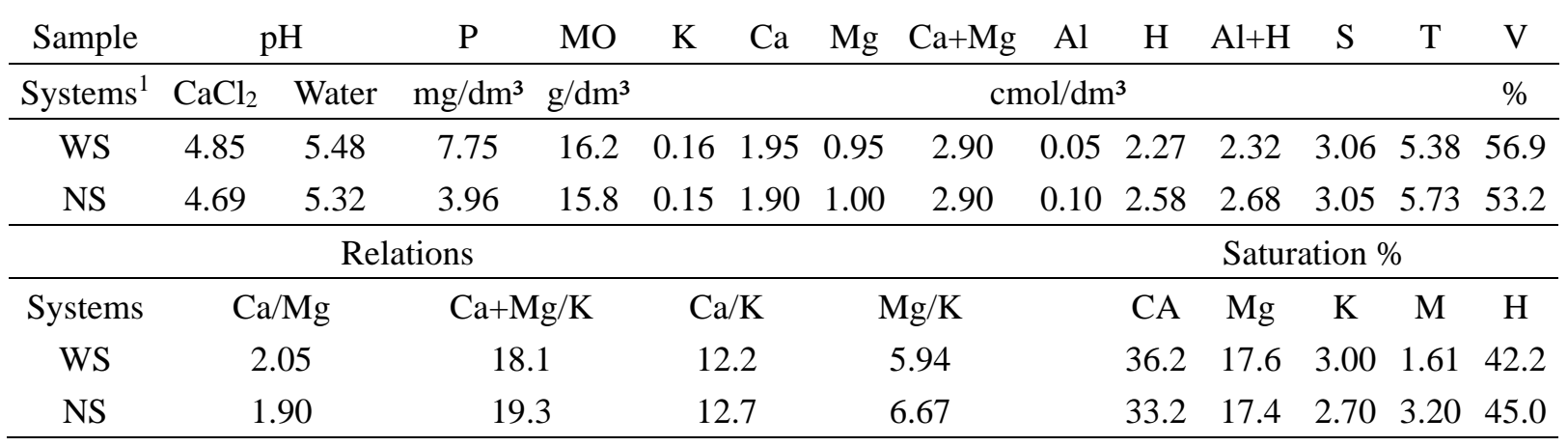

Source: Laboratory of soil analysis and consulting LTDA. ${ }^{1} \mathrm{WS}$ - with shading -wooded $P$. oteroi pasture; NS - no shading - exclusive P. oteroi pasture.

Therefore, the experimental area was cleaned to cultivate the forage, and the native trees were preserved in the area determined as WS pasture system. Subsequently, the area was demarcated in 24 plots (experimental plots) of nine $\mathrm{m}^{2}$. After the transplanting, the seedlings were irrigated until their establishment in the area.

In the FF treatment, the foliar fertilizer was Quimiorgen pasto ${ }^{\circledR}\left(\right.$ six L ha $\left.^{-1}\right)$ plus Niphokam ${ }^{\circledR}$ (two L ha-1). In the SF treatment, soil fertilizer was Simple Superphosphate - SS (390 kg $\mathrm{ha}^{-1}$ ), and the foliar fertilizer was Quimiorgen pasto ${ }^{\circledR}\left(\right.$ six L ha $\left.{ }^{-1}\right)+$ Nipokam $^{\circledR}$ (two L ha-1). These doses have been recommended by the fertilizer manufacturer. In the Tables 2 and 3 are shown the chemical composition of foliar fertilizer registered by a Brazilian's commercial company with the names of Niphokam ${ }^{\circledR}$ and Quimiorgen pasto ${ }^{\circledR}$ (FÊNIX Agro, Tietê, São Paulo).

Table 2. Main chemical composition of Niphokam ${ }^{\circledR}$

\begin{tabular}{ccc}
\hline Composition & Percentage & Concentration \\
\hline Nitrogen & $10 \%$ & $135.0 \mathrm{~g} \mathrm{~L}^{-1}$ \\
Phosphorus $\left(\mathrm{P}_{2} \mathrm{O}_{5}\right)$ & $8 \%$ & $108.0 \mathrm{~g} \mathrm{~L}^{-1}$ \\
Potassium $\left(\mathrm{K}_{2} \mathrm{O}\right)$ & $8 \%$ & $108.0 \mathrm{~g} \mathrm{~L}^{-1}$ \\
Calcium $(\mathrm{Ca})$ & $1 \%$ & $13.5 \mathrm{~g} \mathrm{~L}^{-1}$ \\
Magnesium $(\mathrm{Mg})$ & $0.5 \%$ & $6.75 \mathrm{~g} \mathrm{~L}^{-1}$ \\
Boron $(\mathrm{B})$ & $0.5 \%$ & $6.75 \mathrm{~g} \mathrm{~L}^{-1}$ \\
Copper $(\mathrm{Cu})$ & $0.2 \%$ & $2.70 \mathrm{~g} \mathrm{~L}^{-1}$ \\
Manganese $(\mathrm{Mn})$ & $0.5 \%$ & $6.75 \mathrm{~g} \mathrm{~L}^{-1}$ \\
Zinc $(\mathrm{Zn})$ & $1 \%$ & $13.5 \mathrm{~g} \mathrm{~L}^{-1}$ \\
\hline
\end{tabular}

Sources of data: (Fenix ${ }^{\circledR}$ Agro, 2016). 
Table 3. Main chemical composition of the Quimiorgen pasto ${ }^{\circledR}$

\begin{tabular}{lcc}
\hline Composition & Percentage & Concentration \\
\hline Phosphorus $\left(\mathrm{P}_{2} \mathrm{O}_{5}\right)$ & $20 \%$ & $270.0 \mathrm{~g} \mathrm{~L}^{-1}$ \\
Boron $(\mathrm{B})$ & $0.5 \%$ & $6.75 \mathrm{~g} \mathrm{~L}^{-1}$ \\
Manganese $(\mathrm{Mn})$ & $3 \%$ & $40.5 \mathrm{~g} \mathrm{~L}^{-1}$ \\
Zinc $(\mathrm{Zn})$ & $3 \%$ & $40.5 \mathrm{~g} \mathrm{~L}^{-1}$ \\
\hline
\end{tabular}

Sources of data: $\left(\right.$ Fenix $^{\circledR}$ Agro, 2016).

A pressure equipment was used to applicate the foliar fertilizer, with the following calibration: tip XR 11002; Spout thickness $0.50 \mathrm{~m}$; Gout $=$ Fine; Volume $=200 \mathrm{~L} \mathrm{ha}^{-1}$; Speed $=1 \mathrm{~m} \mathrm{~s}^{-1}=$ $3.6 \mathrm{~km} \mathrm{~h}^{-1}$ and pressure $=1.7$ bar. With this equipment it was applied the fertilizers Quimiorgen Pasto ${ }^{\circledR}$ and Niphokam ${ }^{\circledR}$. To applied SS, it was used $390 \mathrm{~kg} \mathrm{ha}^{-1}$. Thus, each plot was fertilized with $0.351 \mathrm{~kg}$ of SS, distributed along the planting lines, before transplanting the seedlings.

After transplanting $P$. oteroi seedlings in the experimental plots, their development was monitored monthly. As soon as the plants reached $100 \%$ of cover a uniform cut was made at five $\mathrm{cm}$ from the soil. Then, the corresponding foliar fertilizer was applied to each plot. Data collection was from May 2016 to September 2016, during dry season.

One sample of $0.25 \mathrm{~m}^{2}$ per experimental plot was harvested, in each 28 days, to evaluate forage quality and biomass production. The dry matter production per hectare (DMP ha-1) was estimated. From each sample collected was taken a representative subsample. Subsamples were oven dried at $65{ }^{\circ} \mathrm{C} / 72$ hours and finely ground for analysis content of crude protein $(\mathrm{CP})$, ether extract (EE), neutral detergent fiber (NDF), acid detergent fiber (ADF) accordance with methods INCT-CA N-001/1, INCT-CA F-002/1, INCT-CA F-002/1 and INCT-CA F-004/1, respectively (Detmann et al., 2012).

For the measurements of light interception (LI) and leaf area index (LAI), the AccuPAR model device - LP 80 was used. Readings were performed between 11:00 am and 01:00 pm, making an average of two readings in each experimental plot, in both pasture systems (WS and NS). Two measurements were taken simultaneously: above the forage sward and below it. The LAI was estimated simultaneously to the monitoring of light interception by the average of the forage canopy, since the AccuPAR calculates the LAI based on PAR (Photosynthetically Active Radiation) measured above and below the canopy simultaneously with other variables related to the canopy architecture and position of the sun. Sward height (H) was measured simultaneously with the use of a graduated ruler. These measurements were made weekly throughout the experimental period. Light interception (LI, \%) at a given position was calculated as $\left(\mathrm{I}_{0}-\mathrm{I} / \mathrm{I}_{0}\right) \times 100$, where $\left(\mathrm{I}_{0}\right)$ is the irradiance above sward and $(\mathrm{I})$ is the irradiance under the same sward.

The monolith method was used to obtain root and soil to evaluate the ratio between shoot and $\operatorname{root}(\mathrm{S}: \mathrm{R}$ ratio) (Bohm, 1979) at the end of the experiment. Two soil cubes with $25 \mathrm{~cm} \mathrm{x} 25$ 
$\mathrm{cm}$ sides in dept of zero to $25 \mathrm{~cm}$, were sampled in each experimental plot and the roots were washed and separated in a sieve. The shoot was cut. Both shoot and root were dried at $65{ }^{\circ} \mathrm{C}$ (pre-drying) to constant weight to determination dry matter (DM) in accordance with Detmann et al. (2012). The S:R ratio was calculated by dividing the yield in shoot DM by the root DM yield.

The data of sward height $(\mathrm{H})$, light interception (LI), leaf area index (LAI), dry matter (DM), crude protein (CP), ether extract (EE), neutral detergent fiber (NDF), acid detergent fiber $(\mathrm{ADF})$, and dry matter production (DMP) per hectare was analyzed as repeated measures over time using the PROC MIXED of the SAS University (SAS Institute., Inc., Cari, CA). The S:R ratio was analyzed as a single measurement, taken at the end of the experiment. Furthermore, when a significant effect occurred, the means values were compared by $t$ test. Pearson correlation coefficient was used to examine the linear relationship among variables, using PROC CORR of the same software. For all analyses, it was adopted a significance level of 5\%.

\section{Results and Discussion}

There was no interaction between fertilizer type and the pasture systems. Thus, the effects of all variables were analyzed independently (Table 4).

Table 4. Least square means and standard errors of the variable analyzed

\begin{tabular}{|c|c|c|c|c|c|c|c|}
\hline \multirow[b]{2}{*}{ Variables $^{1}$} & \multicolumn{3}{|c|}{ Fertilizer $^{2,3}$} & \multicolumn{2}{|c|}{ Pasture systems ${ }^{2,3}$} & \multicolumn{2}{|c|}{$P$-Value } \\
\hline & $\mathrm{C}$ & FF & SF & WS & NS & Fertilizer & $\begin{array}{l}\text { Pasture } \\
\text { systems }\end{array}$ \\
\hline $\mathrm{H}$ & $10.2 \pm 0.369$ & $9.91 \pm 0.369$ & $9.89 \pm 0.484$ & $9.35 \pm 0.348 b$ & $10.6 \pm 0.323 a$ & 0.850 & 0.016 \\
\hline IL & $38.8 \pm 2.28$ & $35.3 \pm 2.28$ & $42.6 \pm 2.98$ & $40.4 \pm 2.14$ & $37.4 \pm 1.99$ & 0.182 & 0.316 \\
\hline DM & $35.5 \pm 0.537^{\mathrm{a}}$ & $36.8 \pm 0.537 a$ & $32.7 \pm 0.705 b$ & $33.2 \pm 0.506 b$ & $36.8 \pm 0.470 \mathrm{a}$ & 0.001 & $<.0001$ \\
\hline $\mathrm{CP}$ & $7.32 \pm 0.151 b$ & $7.50 \pm 0.151 b$ & $8.81 \pm 0.199 a$ & $8.61 \pm 0.143 a$ & $7.15 \pm 0.132 b$ & $<.0001$ & $<.0001$ \\
\hline $\mathrm{EE}$ & $1.61 \pm 0.083$ & $1.67 \pm 0.083$ & $1.83 \pm 0.109$ & $1.79 \pm 0.078$ & $1.61 \pm 0.072$ & 0.309 & 0.111 \\
\hline NDF & $67.7 \pm 0.430$ & $67.6 \pm 0.430$ & $67.4 \pm 0.563$ & $67.4 \pm 0.405$ & $67.7 \pm 0.375$ & 0.936 & 0.599 \\
\hline $\mathrm{ADF}$ & $37.2 \pm 0.384$ & $36.7 \pm 0.384$ & $35.7 \pm 0.503$ & $36.2 \pm 0.362$ & $36.8 \pm 0.335$ & 0.102 & 0.222 \\
\hline DMP & $0.999 \pm 0.015 \mathrm{a}$ & $1.03 \pm 0.015 \mathrm{a}$ & $0.920 \pm 0.019 b$ & $0.935 \pm 0.014 b$ & $1.035 \pm 0.013 \mathrm{a}$ & 0.001 & 0.0001 \\
\hline
\end{tabular}

${ }^{1} \mathrm{H}$ (sward height, cm); LI (light interceptation, \%); DM (dry matter, \%); CP (crude protein, \% $\mathrm{DM}$ ); EE (ethereal extract, \%DM); NDF (neutral detergent fiber, \%DM); ADF (acid detergent fiber, \%DM); DMP (Dry matter production ton $\left.\mathrm{ha}^{-1}\right){ }^{2} \mathrm{C}$ - no fertilization; FF - foliar fertilizer for pasture and SF- soil fertilizer + foliar fertilizer. WS - with shading - wooded $P$. oteroi pasture -; NS - no shading - exclusive P. oteroi pasture.$-{ }^{3}$ Means followed by the same lower case letters on the lines do not differ significantly by the t test $(p<0.05)$.

There was no effect $(p>0.05)$ of type of fertilization on sward height. However, a pasture systems effect $(p<0.05)$ was observed on this characteristic. Sward height reached lower values under shaded conditions when compared to full sunlight, a result which was contrary to expectations because shading can reduce solar radiation with consequent taller and longer stems in their search for luminosity (Martuscello et al., 2009; Souza et al., 2007). However, some other authors have reported similar results to this study (Carvalho et al., 1995; Eriksen \& Whitney, 1981) while Santos (2014) did not find significant differences in height under shading in Brachiaria brizantha cv. Marandu, Brachiaria decumbens cv. Basilisk, and Panicum maximum cv. Tanzania. According to Carvalho et al. (1995) the reduction of height under the effect of shading may be related to the tree components that prevent luminosity. In 
this study, grasses were transplanted in an already established understory.

There were no significant differences $(p>0.05)$ between $\mathrm{C}$ and FF for DM and DMP. The lowest DM and DMP contents were observed in SF fertilization. Nevertheless, Pietroski et al. (2015) observed higher dry matter using a dose of $35.24 \mathrm{~kg} \mathrm{ha}^{-1}$ of $\mathrm{N}$ in Panicum maximum cv. Mombaça.

DM and DMP were affected significantly by pasture systems. The dry matter content of $P$. oteroi was reduced by shade at about $10 \%$. According to Gobbi et al. (2011) the shaded system can modify leaf anatomy reducing sclerenchymatous tissue and thickness of the palisade parenchyma, thus, reducing the dry matter content. On the other hand, this decrease in thickness of the palisade parenchyma, which contains most chloroplasts, reduces net photosynthetic rate (Boardman, 1977; Paciullo et al., 2007). These same factors may also have influenced forage quality. There were significant differences $(p<0.05)$ among fertilizers type as well as between the pasture systems in CP content. Higher $(p<0.05)$ values of $\mathrm{CP}$ content were observed for the treatment SF and WS (Table 5).

According to Eriksen and Whitney (1981), the dry matter content decreased with shading, but increased the N content. Several studies demonstrated that shading increased crude protein in grasses. Santos (2014) evaluated four shade levels (0, 30, 50 and $70 \%)$ and observed the highest CP content with the level of $70 \%$ in Brachiaria decumbens, Brachiaria brizantha cv. Marandu, and Panicum maximum cv. Tanzânia (18\%, 18\% e 16\% respectively). Barro et al. (2008) found an average increase of $2 \%$ of the CP content in Lolium multiflorum, Avena strigosa. and Avena sativa submitted to the shading of Pinus elliottii.

The SF fertilization (Soil fertilizer + Foliar fertilizer) also contributed to a higher CP content. In general, the nutrients offered by SF may have acted directly on the photosynthetic process and on the enzymatic metabolism, resulting in larger photoassimilates (Rosolem, 2002).

The CP mean content for P. oteroi in the control treatment was $7.32 \%$ a satisfactory value considering the dry period and the fact that the CP levels are influenced by growth stage and soil fertility. According to Taylor and Allison (1982) another factor which seems to have affected the CP level in three warmed-season grasses involved the leaf: stem ratio.

As a result, just shading reduced significantly $(p<0.05)$ the shoot/root ratio of $P$. oteroi that reflected in an increase of root mass in relation to the shoot, probably an adaptive characteristic of the species that allows greater survival (Table 5). 
Table 5. Least squares means and standard errors of the shoot:root ratio of the P. oteroi submitted to fertilization and shading

\begin{tabular}{|c|c|c|c|c|c|c|c|}
\hline \multirow[b]{2}{*}{ Variables $^{1}$} & \multicolumn{3}{|c|}{ Fertilizer $^{2}$} & \multicolumn{2}{|c|}{ Pasture systems ${ }^{3}$} & \multicolumn{2}{|c|}{$P$-Value } \\
\hline & $\mathrm{C}$ & $\mathrm{FF}$ & SF & WS & NS & Fertilizer & Pasture systems \\
\hline$S: R$ & $1.16 \pm 0.063$ & $1.23 \pm 0.063$ & $1.07 \pm 0.082$ & $0.958 \pm 0.06 \mathrm{~b}$ & $1.35 \pm 0.054 \mathrm{a}$ & 0.365 & 0.0002 \\
\hline
\end{tabular}

${ }^{1} \mathrm{~S}: \mathrm{R}$ - shoot:root ratio. ${ }^{2,3}$ Means followed by the same lower case letters on the lines do not differ significantly by the $\mathrm{t}$ test $(p<0.05)$. C - no fertilization; FF - foliar fertilizer for pasture and SF- soil fertilizer + foliar fertilizer. WS - with shading - wooded P. oteroi pasture -; NS no shading - exclusive P. oteroi pasture.

An increase in shoot: root ratio of grass species under shading has been reported by several authors. Santos et al. (2011) obtained opposite results with Brachiaria brizantha and Brachiaria humidicola, under conditions of $70 \%$ shading. According to Durr and Rangel (2000) the increase of the aerial part is a strategy of the plant to increase the ability to intercept larger amounts of radiation. For Comas et al. (2013) this adaptive response of the shoot: root ratio to environmental conditions should be associated with the evaluation of root morphology or architecture traits.

Significant correlations among variables were reported (Table 6). There was a high and a negative correlation between $\mathrm{S}: \mathrm{R}$ ratio and $\mathrm{CP}$. This result can be explained by lower $(p<0.05)$ leaf: stem ratio when $S: R$ increases as well as the positive relationship between DM, DMP, H and CP.

Table 6. Pearson's coefficient among analyzed variables including different pasture systems the in Cerrado-Pantanal transition region

\begin{tabular}{ccccccccc}
\hline Variables $^{1}$ & LI & LAI & DM & CP & EE & NDF & ADF & DMP \\
\hline H & 0.116 & $-0.196^{*}$ & 0.006 & -0.186 & -0.072 & 0.165 & $0.255^{* *}$ & 0.042 \\
LI & 1 & 0.086 & $0.295^{* *}$ & 0.012 & 0.043 & $-0.263^{* *}$ & $-0.313^{* *}$ & $0.279^{* *}$ \\
LAI & & 1 & -0.052 & $0.345^{* *}$ & $0.233^{*}$ & -0.143 & $-0.232^{*}$ & -0.091 \\
DM & & & 1 & $-0.557^{* * *}$ & -0.046 & -0.186 & $-0.422^{* * *}$ & $0.991^{* * *}$ \\
CP & & & & 1 & 0.087 & $-0.297 * *$ & -0.131 & $-0.623^{* * *}$ \\
EE & & & & & 1 & -0.088 & -0.114 & -0.049 \\
NDF & & & & & & 1 & $0.504^{* * *}$ & -0.095 \\
ADF & & & & & & & 1 & $-0.362^{* * *}$ \\
\hline
\end{tabular}

${ }^{1} \mathrm{H}$ (plant height, cm); LI (light interceptation, \%); LAI (leaf area index); DM (dry matter, \%); $\mathrm{CP}$ (crude protein, \% DM); EE (ethereal extract, \%DM); NDF (neutral detergent fiber, \%DM); ADF (acid detergente fiber, \%MS); DMP (dry matter production ton $\mathrm{ha}^{-1}$ ).* $p<0.05$; ** $p<0.01, * * * p<0.001$.

There was an interaction among the pasture systems, fertilization and month of fertilization on the LAI variable (Table 7). 
Table 7. Least squares means and standard errors of the leaf area index (LAI) according to two pasture systems (WS and NS) and month of fertilization in WS

\begin{tabular}{|c|c|c|c|c|}
\hline \multirow[b]{2}{*}{ Month } & \multicolumn{3}{|c|}{ Fertilizer $^{1}$} & \multirow{2}{*}{$\begin{array}{c}P \text {-Value } \\
\text { Fertilizer }\end{array}$} \\
\hline & $\mathrm{C}$ & FF & SF & \\
\hline \multicolumn{5}{|c|}{$\underline{\mathrm{WS}^{2}}$} \\
\hline May & $0.045 \pm 0.016$ & $0.035 \pm 0.016$ & $0.060 \pm 0.023$ & 0.705 \\
\hline June & $0.032 \pm 0.008 \mathrm{a}$ & $0.015 \pm 0.008 b$ & $0.060 \pm 0.011 \mathrm{a}$ & 0.048 \\
\hline July & $0.070 \pm 0.023$ & $0.092 \pm 0.023$ & $0.080 \pm 0.033$ & 0.802 \\
\hline August & $0.260 \pm 0.080$ & $0.115 \pm 0.080$ & $0.410 \pm 0.112$ & 0.162 \\
\hline September & $0.230 \pm 0.054 b$ & $0.032 \pm 0.054 c$ & $0.495 \pm 0.077 \mathrm{a}$ & 0.005 \\
\hline \multicolumn{5}{|c|}{$\mathrm{NS}^{2}$} \\
\hline Total period & $0.053 \pm 0.009$ & $0.062 \pm 0.009$ & $0.049 \pm 0.011$ & 0.656 \\
\hline
\end{tabular}

${ }^{1} \mathrm{C}$ - no fertilization; FF - foliar fertilizer for pasture and SF- soil fertilizer + foliar fertilizer. WS - with shading - wooded P. oteroi pasture -; NS - no shading - exclusive P. oteroi pasture. ${ }^{1,2} \mathrm{~L}$ Means followed by the same lower case letters on the lines do not differ significantly by the $\mathrm{t}$ test $(p<0.05)$.

Higher values $(p<0.05)$ of LAI occurred in the months of August and September in the fertilizer treatment with higher levels of SF, the effect of fertilization occurred at the end of the drought season. This fact can be explained by higher tillering because it was observed that P. oteroi kept its height during the drought. The lower levels of LAI observed in the wooded pasture with shading may be due to factors such as the reduction of tillers (Souza et al., 2007). For Paciullo et al. (2007), the lower the incidence of light that enters the wood, the lower the LAI and the tiller density in the understory.

There was no significant correlation between LAI and LI as well as H and LI as expected (Table 6). LI values were very slow (bellow 50\%) for P. oteroi in both pasture systems (Figure 2 and 3).

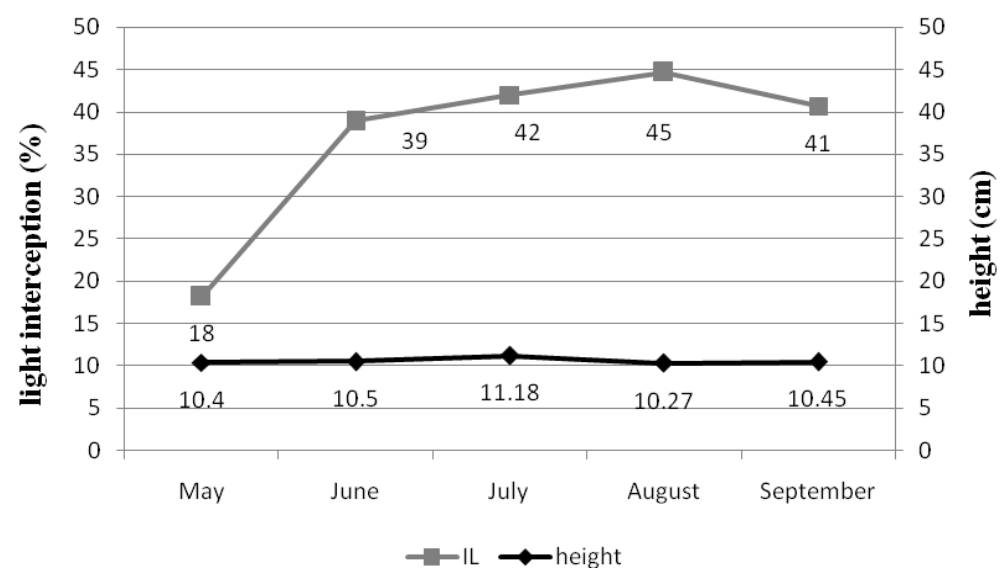

Figure 2. Monitoring of light interception and height of P. oteroi not submitted to shading (NS system) 


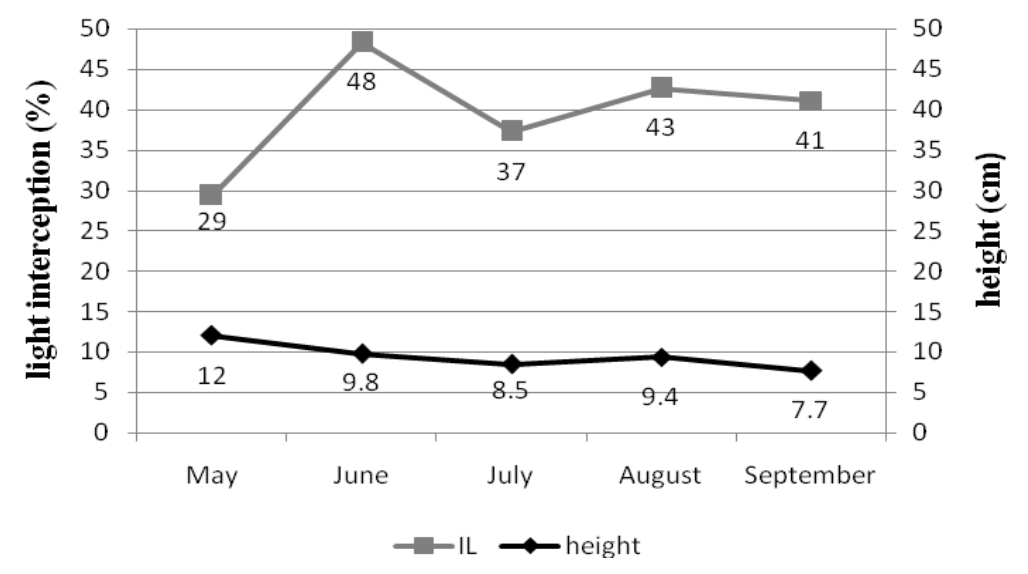

Figure 3. Monitoring of light interception and height of P. oteroi submitted to shading (WS system)

Considering that environmental limitations during the hydrological year probably affected the total establishment of $P$. oteroi, mainly during the time of transplantation of seedlings, the results indicated that sward architecture (e.g., leaf shape and size) and tiller density may have resulted in lower LAI and LI. Further studies are necessary for a more profound knowledge of the management of the species in different environmental conditions to be obtained.

\section{Conclusion}

The shading condition in the wooded pasture system and the use of fertilization (foliar and soil) improved the crude protein level of $P$. oteroi during the drought. Thus, economic viability studies are necessary for decisions to be made.

Fertilization (foliar and soil) of $P$. oteroi provided higher LAI values at end of the drought, which requires long-term studies for monitoring this variable.

P. oteroi probably developed adaptation strategies to cope with the environmental conditions such as variations in the morpho-physiological traits, shown in this study by low shoot/root ratio, sward height, nutritional value, LAI and LI.

\section{Acknowledgments}

The study was supported by the FUNDECT - Foundation for Support to the Development of Teaching, Science and Technology of the State of Mato Grosso do Sul [grant number SIAFEM/024370]. Support Embrapa Pantanal, UEMS, Fenix ${ }^{\circledR}$ Agro e GEFE. 


\section{References}

Balbino, L. C., Kichel, A. N., Bungenstab, D. J., \& Almeida, R. G. (2012). Integration systems what they are, their advantages and limitations. Systems of crop-livestock-forest integration: Sustainable Production, 1, 12-18.

Barro, R. S., Saibro, J. C., Medeiros. R. B., Da Silva, J. L. S., \& Varella, A. C. (2008). Forage yield and nutritive value of cool-season annual forage grasses shaded by Pinus elliottii trees and at full-sun. Brazilian Journal of Animal Science, 37, 1721-1727. https://doi.org/10.1590/S1516-35982008001000002.

Boardman, N. K. (1977). Comparative photosynthesis of sun and shade plants. Review of Plant Physiology, 28, 355-377. https://doi.org/10.1146/annurev.pp.28.060177.002035

Bohm, W. (1979). Methods of studying root systems. New york: springer-verlag, 189. https://doi.org/10.1007/978-3-642-67282-8

Carvalho, M. M., Freitas, V. P., \& Andrade, A. C. (1995). Initial growth of five tropical grasses in a sub-forest of Angico-vermelho (Anadenanthera macrocarpa benth.). Pasturas Tropicales 17, 24-30.

Carvalho, M. M., Freitas, V. P., \& Xavier, D. F. (2002). Initial flowering, dry matter yield and nutritive value of tropical forage grasses under natural shading. Pesquisa Agropecuária Brasileira, 37, 717-722. https://doi.org/10.1590/S0100-204X2002000500018

Comas, L. H., Becker, S. R., Cruz, V. M. V., Byrne, P. F., \& Dierig D. A. (2013). Root traits contributing to plant productivity under drought. Frontiers in Plant Science, 4, 442. https://doi.org/10.3389/fpls.2013.00442

Craine, J. M., \& Dybzinski, R. (2013). Mechanisms of plant competition for nutrients, water and light. Functional Ecology, 27, 833-840. https://doi.org/10.1111/1365-2435.12081

Da Silva, R. G. (2006). Tree shade evaluation and prediction in cattle feedlots. Engenharia Agrícola, 26, 268-281. https://doi.org/10.1590/S0100-69162006000100029

Detmann, E., Souza, M. A., Valadares Filho, S. C., Queiroz, A. C., Berchielli, T. T., Saliba, E. O. S., ... Azevedo, J. A. G. (2012). Métodos para análise de alimentos (1 ed). Visconde do Rio Branco: Suprema. 214.

Durr, P. A., \& Rangel, J. (2000). The response of Panicum maximum to a simulated subcanopy environment. I. Soil x shade interaction. Tropical Grasslands, 34, 110-117.

Eriksen, F. I., \& Whitney, A. S. (1981). Effects of light intensity on growth of some tropical forage species. I. Interaction of light intensity and nitrogen fertilization on six forage grasses. Agronomy Journal, 73,

427-433.

https://doi.org/10.2134/agronj1981.00021962007300030011x

Euclides, V. P. B., Valle, C. B., Macedo, M. C. M., Almeida, R. G., Montagner, D. B., \& Barbosa, R. A. (2010). Brazilian scientific progress in pasture research during the first decade of XXI century. Brazilian Journal of Animal Science, 39, 151-168. 
https://doi.org/10.1590/S1516-35982010001300018

Fenix ${ }^{\circledR}$ Agro. (2016). Available: http://quimifol.com.br/produtos.asp [Sept 19, 2016].

Gobbi, K. F., Garcia, R., Ventrella, M. C., Neto, A. F. G., \& Rocha, G. C. (2011). Specific leaf area and quantitative foliar anatomy of signalgrass and forage peanut submitted to shading. Brazilian Journal of Animal Science, 40, 1436-1444. https://doi.org/10.1590/S1516-35982011000700006

Gratani, L. (2014). Plant phenotypic plasticity in response to environmental factors. Advances in Botany, 2014, 17. https://doi.org/10.1155/2014/208747

INMET. (2016). National Institute of Meteorology. Available: http://inmet.gov.br/portal/[Sept $25,2016]$.

Martuscello, J. A., Jank, L., Gontijo Neto, M. M., Laura, V. A., \& Cunha, D. N. F. V. (2009). Genus Brachiaria grass yeilds under different shade levels. Brazilian Journal of Animal Science, 38, 1183-1190. https://doi.org/10.1590/S1516-35982009000700004

Paciullo, D. S. C., Carvalho, C. A. B., Aroeira, L. J. M., Orenz, M. F., Lopes, F. C. F., \& Rossiello, R. O. P. (2007). Morphophysiology and nutritive value of signalgrass under natural shading and full sunlight. Pesquisa Agropecuária Brasileira, 42, 573-579. https://doi.org/10.1590/S0100-204X2007000400016

Pietroski, M., Oliveira, R., \& Caione, G. (2015). Foliar application of nitrogen on Mombaça guinea grass (Panicum maximum cv. Mombaça). Revista de Agricultura Neotropical, 2, 49-53. https://doi.org/10.32404/rean.v2i3.684

Rosolem, C. A. (2002). Recomendação e aplicação de nutrientes via foliar. (1 ed). Lavras: UFLA/FAEPE: 98.

Salton, J. C., Mercante, F. M., Tomazi, M., Zanatta, J. A., Concenço, G., Silva, W. M., \& Retore, M. (2014). Integrated crop-livestock system in tropical Brazil: Toward a sustainable production system. Agriculture, Ecosystems \& Environmente, 190, 70-79. https://doi.org/10.1016/j.agee.2013.09.023

Santos, C. G. (2014). Evaluation of tropical grasses at different levels of shading. Revista Científica de Produção Animal. https://doi.org/10.15528/2176-4158/rcpa.v16n1p68-78

Santos, S. A., Abreu, U. G. P., Tomich, T. R., \& Comastri Filho, J. A. (2011). Traditional beef cattle ranching and sustainable production in the Pantanal. In: Junk, W. J., Silva, C. J., Nunes da Cunha, C., Wantzen, K. M. (Eds.), The Pantanal: Ecology, Biodiversity and Sustainable Management of a Large Neotropical Seasonal Wetland. Sofia: Pensoft Publishers: 755-774.

Siebenkäs, A., Schumacher. J., \& Roscher, C. (2015). Phenotypic plasticity to light and nutrient availability alters functional trait ranking across eight perennial grassland species. AoB Plants, 7, 029. https://doi.org/10.1093/aobpla/plv029

Souza, L. F., Maurício, R. M., Gonçalvez, L. C., Saliba, E. O. S., \& Moreira, G. R. (2007). 


\section{Macrothink}

Journal of Agricultural Studies

ISSN 2166-0379 2020, Vol. 8, No. 3

Productivity and nutritional value of Brachiaria brizantha cv. Marandu in a silvopastoral system. Brazilian Journal of Veterinary and Animal Sciences, 59, 1029-1037. https://doi.org/10.1590/S0102-09352007000400032

Taylor, R. W., \& Allison, D. W. (1982). Response of three warm-season grasses to varying fertility levels on five soils. Canadian Journal of Plant Science, 62, 657-665. https://doi.org/10.4141/cjps82-096

\section{Copyright Disclaimer}

Copyright for this article is retained by the author(s), with first publication rights granted to the journal.

This is an open-access article distributed under the terms and conditions of the Creative Commons Attribution license (http://creativecommons.org/licenses/by/4.0/). 